\title{
Molecular phylogeny of the genus Saguinus (Platyrrhini, Primates) based on the ND1 mitochondrial gene and implications for conservation
}

\author{
Claudia Helena Tagliaro ${ }^{1}$, Horacio Schneider ${ }^{2}$, Iracilda Sampaio ${ }^{2}$, Maria Paula Cruz Schneider ${ }^{3}$, Marcelo \\ Vallinoto $^{2}$ and Michael Stanhope ${ }^{4}$ \\ ${ }^{1}$ Universidade Federal do Pará, Campus de Bragança, Laboratório de Conservação e Biologia Evolutiva, \\ Bragança, Pará, Brazil. \\ ${ }^{2}$ Universidade Federal do Pará, Campus de Bragança, Laboratório de Genética e Biologia Molecular, \\ Bragança, Pará, Brazil. \\ ${ }^{3}$ Universidade Federal do Pará, Centro de Ciências Biológicas, Departamento de Genética, Laboratório de \\ Polimorfismo de DNA, Belém, Pará; Brazil. \\ ${ }^{4}$ Queen's University of Belfast, Belfast, Northern Ireland, UK.
}

\begin{abstract}
The systematics of the subfamily Callitrichinae (Platyrrhini, Primates), a group of small monkeys from South America and Panama, remains an area of considerable discussion despite many investigations, there being continuing controversy over subgeneric taxonomic classifications based on morphological characters. The purpose of our research was to help elucidate the phylogenetic relationships within the monkey genus Saguinus (Callitrichinae) using a molecular approach to discover whether or not the two different sections containing hairy-faced and bare-faced species are monophyletic, whether Saguinus midas midas and Saguinus bicolor are more closely related than are S. midas midas and Saguinus midas niger, and if Saguinus fuscicollis melanoleucus and Saguinus fuscicollis weddelli really are different species. We sequenced the 957 bp ND1 mitochondrial gene of 21 Saguinus monkeys (belonging to six species and nine morphotypes) and one Cebus monkey (the outgroup) and constructed phylogenetic trees using maximum parsimony, neighbor joining, and maximum likelihood methods. The phylogenetic trees obtained divided the genus Saguinus into two groups, one containing the small-bodied species $S$. fuscicollis and the other, the large-bodied species S. mystax, S. leucopus, S. oedipus, S. midas, S. bicolor. The most derived taxa, S. midas and S. bicolor, grouped together, while S. fuscicollis melanoleucus and S. $f$. weddelli showed divergence values that did not support the division of these morphotypes into subspecies. On the other hand, $S$. midas individuals showed divergence compatible with the existence of three subspecies, two of them with the same morphotype as the subspecies $S$. midas niger. The results of our study suggest that there is at least one Saguinus subspecies that has not yet been described and that the conservation status of Saguinus species and subspecies should be carefully revised using modern molecular approaches.
\end{abstract}

Key words: Saguinus, Callitrichinae, ND1, phylogeny, mtDNA, conservation.

Received: October 20, 2003; Accepted: May 16, 2004.

\section{Introduction}

South American and Panamanian small monkeys (marmosets and tamarinds) are classified within the subfamily Callitrichinae (Primates, Platyrrhini, Ceboidea, Cebidae) (Rosenberger, 1981). In their assessment of the diversity of the New World primates, Rylands et al. (2000) stated that the Callitrichinae contained the six genera Callimico (Goeldi's monkey), Callithrix (Atlantic marmo-

Send correspondence to C.H. Tagliaro. Universidade Federal do Pará, Campus de Bragança, Laboratório de Conservação e Biologia Evolutiva, Bragança, Pará, Brazil. E-mail: tagliaro@ ufpa.br. sets), Cebuella (pygmy marmosets), Leontopithecus (lion or golden tamarins), Mico (Amazonian marmosets) and Saguinus (tamarins), although a previous molecular phylogeny study of the New World monkeys by Schneider et al. (1996) had grouped Callithrix, Cebuella and Mico together in the genus Callithrix. The basal genus of the Callitrichinae is Saguinus (Barroso et al., 1997; Chaves et al., 1999; Schneider et al., 1996), a widely distributed genus which occurs from the Amazon basin northward into Panama (Hershkovitz, 1977; Rylands et al., 1993), with both Leontopithecus and Saguinus being commonly known as tamarins (Rosenberger, 1978). 
The traditional classification of Hershkovitz (1977, 1979, 1982) for the Saguinus tamarins contains 10 different species, some of which have been further divided into subspecies which now total 33 taxonomic morphotypes. Hershkovitz (1977) used facial pelage to divide the species Saguinus into three sections: the hairy-faced tamarin section containing the Saguinus nigricollis group or whitemouthed tamarins (S. nigricollis, S. fuscicollis) as well as the Saguinus mystax group or mustached tamarins ( $S$. mystax, S. labiatus, $S$. imperator) and the Saguinus midas group or midas tamarins (S. midas midas, S. midas niger); the mottled-faced tamarin section containing Saguinus inustus only); and the bare-faced tamarin section containing the Saguinus bicolor group ( $S$. b. bicolor, $S . \quad b$. ochraceus, S. b. martinsi) and the Saguinus oedipus group (S. oedipus, S. leucopus). The most primitive group is believed to be the white-mouthed tamarins (Hershkovitz, 1977). Mittermeier et al. (1988) considered that there was the same total number of Saguinus taxonomic morphotypes (i.e. 33), although they divided them into 12 species instead of the 10 accepted by Hershkovitz (1977). The Brazilian taxa of Callitrichinae primates was studied by CoimbraFilho (1990), who partially agreed with Hershkovitz (1977) but grouped the three Saguinus subspecies S. fuscicollis melanoleucus, S. fuscicollis crandalli and S. fuscicollis acrensis into one independent species, Saguinus melanoleucus, made up of three subspecies $(S . \mathrm{m}$. melanoleucus, S. m. crandalli, S. m. acrensis). Rylands et al. (1993) generally followed Hershkovitz's (1977) classifications as regards sections and groups, except that they agreed with Natori and Hanihara (1992) that a new group should be formed by removing $S$. midas from the hairy-faced section and S. bicolor from the bare-faced section. In a subsequent paper, Rylands et al. (1995) accepted 12 distinct species and a total of 32 taxonomic morphotypes (S. f. acrensis was not considered a valid form) but still agreed with Hershkovitz (1977) that the Saguinus tamarins should be divided into three sections, although they modified the structure of the groups as follows: the hairy-faced tamarin section containing only the nigricollis group ( $S$. nigricollis, S. fuscicollis, S. tripartitus) and the mystax group (S. mystax, S. imperator, S. labiatus, S. midas), formed by combining the mustached and midas groups; the mottled-faced tamarin section containing S. inustus only; and the bare-faced tamarin section consisting of the bicolor group, containing the three $S$. bicolor subspecies, and the oedipus group (S. oedipus, S. geoffroyi, S. leucopus). More recently, Rylands et al. (2000) re-evaluated the taxonomic status of some forms and reclassified the genus Saguinus into 15 distinct species with a total of 33 morphotypes, including S. labiatus rufiventer.

Along with traditional methods, molecular data obtained from primate DNA is providing a new approach to taxonomic classifications (Schneider et al., 1993; Goodman et al., 1998; Schneider et al., 1996; Schneider, 2000).
Several fragments of mitochondrial DNA (mtDNA) have recently been sequenced from members of the Callitrichinae and have been shown to be useful for phylogenetic analysis between genera and at the subgeneric level (Jacobs et al., 1995; Tagliaro et al., 1997; Pastorini et al., 1998; Jacobs-Cropp et al., 1999; Tagliaro et al., 2000; Van Roosmalen et al., 2000). Phylogenetic trees based on cytochrome $b$ and D-loop sequence data obtained by Jacobs et al. (1995) using eight Saguinus species (including six subspecies of S. fuscicollis) and Jacobs-Cropp et al. (1999) using 12 Saguinus species (some of the species subdivided, totalizing 23 subspecies) suggest that Saguinus should be divided into two groups. The trees obtained by JacobsCropp et al. (1999) grouped the tamarins studied into a small-bodied clade (S. fuscicollis spp., S. tripartitus and $S$. nigricollis) and a large-bodied clade (S. labiatus, S. imperator, S. mystax spp., S. inustus, S. geoffroyi, S. oedipus, $S$. leucopus, S. midas spp. and S. bicolor spp.).

Although nuclear genes are usually too conservative to allow evaluation of close taxonomic relationships (Avise, 1994), Canavez et al. (1999) obtained significant results with respect to the phylogenetic relationships within the Callitrichinae at the subgeneric level by sequencing the first three exons and introns of the $\beta_{2}$-microglobulin nuclear gene. According to Canavez et al. (1999), $S$. fuscicollis appeared as the first divergent lineage within the genus Saguinus followed by an unresolved trichotomy ( $S$. mystax-S. imperator, S. midas-S. bicolor, and S. oedipus), this research showing $S$. midas midas grouping with $S$. bicolor rather than $S$. midas niger. On the other hand, the biochemical analysis carried out by Meireles et al. (1997) and the mitochondrial results obtained by Jacobs-Cropp et al. (1999) showed that the $S$. midas subspecies (S. m. midas and $S$. m. niger) are closely related and are separated from the $S$. bicolor clade (S. b. martinsi, S. b. bicolor, S. $b$. ochraceus).

The work presented in this paper examined the phylogenetic relationships between species and subspecies of the genus Saguinus based on ND1 nucleotide sequences with the aim of discovering whether or not the two different sections containing the hairy-faced and bare-faced sections are monophyletic, whether S. bicolor and S. midas midas are more closely related to each other than to $S$. midas midas and S. midas niger, and if are S. fuscicollis melanoleucus and S. fuscicollis weddelli really are different species. The conservation status of Saguinus is also discussed in the light of the results of the phylogenetic analysis.

\section{Materials and Methods}

The Saguinus tamarin species and subspecies used (a total of 21) are shown in Table 1 and their geographical distribution in Figure 1. Since Saguinus is basal to the other Callitrichinae (Schneider et al., 1996; Barroso et al., 1997; Chaves et al., 1999;) the outgroup could not come from this 
Table 1 - Taxonomic and geographical data concerning the Saguinus specimens used. Classification according to Hershkovitz (1977).

\begin{tabular}{|c|c|c|c|c|c|}
\hline Section & Group & $\begin{array}{l}\text { Saguinus species or } \\
\text { subspecies }\end{array}$ & $\begin{array}{l}\text { Number of } \\
\text { specimens }\end{array}$ & Specimen code & Geographical origin \\
\hline \multirow[t]{5}{*}{ Hairy-faced } & nigricollis & S. fuscicollis weddelli & 6 & $77,78,79,80,112,113$ & Rio Jamari, Rondônia, Brazil \\
\hline & & S. fuscicollis melanoleucus & 1 & 137 & Rio Envira (left bank), Acre, Brazil \\
\hline & mystax & S. mystax mystax & 2 & 45,46 & $\mathrm{CNP}^{1 *}$ \\
\hline & midas & S. midas midas & 2 & 133,134 & $\mathrm{CNP}^{1 *}$ \\
\hline & & S. midas niger & 4 & $37,38,39,40$ & Tucuruí, Pará, Brazil \\
\hline \multirow[t]{4}{*}{ Bare-faced } & bicolor & S. bicolor bicolor & 2 & 117,118 & $\mathrm{CPRJ}^{2 *}$ \\
\hline & & S. bicolor martinsi & 2 & 131,132 & $\mathrm{CNP}^{1 *}$ \\
\hline & oedipus & S. oedipus oedipus & 1 & 125 & Colombia $^{*}$ \\
\hline & & S. leucopus & 1 & 126 & Colombia ${ }^{*}$ \\
\hline
\end{tabular}

*Exact origin unknown.

${ }^{1}$ Centro Nacional de Primatas, Belém, Pará, Brazil.

${ }^{2}$ Centro de Primatologia do Rio de Janeiro, Rio de Janeiro, Brazil.

subfamily, because of which we used the monkey Cebus apella (Cebinae, Cebidae), a closely related taxon, as the outgroup. Blood samples $(3 \mathrm{~mL})$ were collected from the femoral vein by anesthetizing each animal using $10 \mathrm{mg} \mathrm{kg}^{-1}$ body weight of Ketalar. The collections were carried out by personnel (see acknowledgments) in the institutions holding the monkeys or from animals captured in the field and subsequently released, in either case the blood samples were kept in ice until analyzed.

Total DNA was extracted from each blood sample using the protocol described by Sambrook et al. (1989). For each monkey sampled the sequence of a $1321 \mathrm{bp}$ fragment spanning the ND1 fragment and flanking regions of the mi-

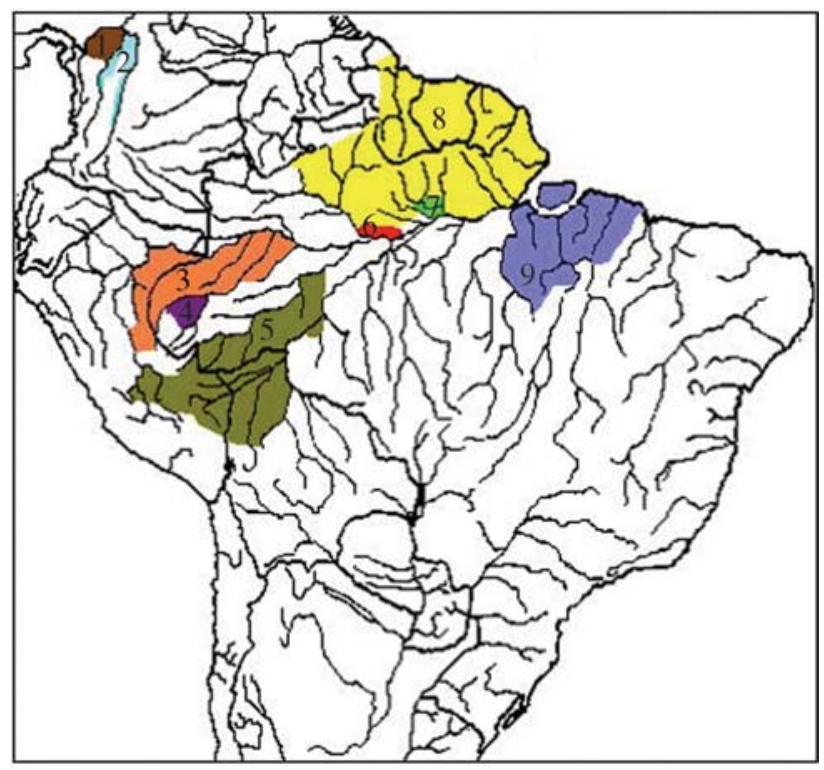

Figure 1 - Geographical distribution of the Saguinus specimens used in our study. 1: S. oedipus; 2: S. leucopus; 3: S. mystax mystax; 4: S. fuscicollis melanoleucus; 5: S. fuscicollis weddelli; 6: S. bicolor bicolor; 7: S. bicolor martinsi; 8: S. midas midas; 9: S. midas niger. Adapted from Rylands et al. (1993). tochondrial DNA was determined by the direct sequencing of PCR-amplified fragments obtained using a 5'-CTACGT GATCTGAGTTCAGACCGG-3' (forward) and 5'-AGGGTATAACCAACATTTTCGGGGTATG-3' (reverse) primer (both designed by Dr. M. Stanhope). In order to eliminate any false priming products that occasionally arise in the original genomic DNA, a second (internal) PCR was performed on the first PCR using the same forward primer and a 5'-CCCGATAGCTTATTTAGCTGACCTT AC-3' reverse primer, the internal primers used (Table 2) being designed by Dr. C. Tagliaro. The reaction protocol consisted of initial denaturing at $94^{\circ} \mathrm{C}$ for 3 min, 30 cycles of one minute at $94^{\circ} \mathrm{C}$ and three minutes at $65^{\circ} \mathrm{C}$ followed by a final extension at $65^{\circ} \mathrm{C}$ for ten minutes. The DNA sequences were determined using dye terminator cycle sequencing reactions and a model $373 \mathrm{~A}$ automatic sequencer according to protocols supplied by the manufacturers (Applied Biosystems, Foster, CA, USA), additional internal sequencing primers being designed as necessary. Although the sequenced fragment was $1321 \mathrm{bp}$, only $957 \mathrm{bp}$ sequences (including initiation and ending codons) corresponding exclusively to the ND1 gene were considered in the analysis.

Initial sequence alignments were performed using the BioEdit (Hall, 1999) and Clustal W (Thompson et al., 1994) programs. The nucleotide frequencies and transition/transversion ratio were obtained using the Mega 2 software (Kumar et al. 2001) and the saturation test was performed using the DAMBE program (Xia and Xie, 2001). The nucleotide sequence data for the sequences used in this paper were deposited in GenBank under accession numbers AY579985 to AY579990, AY599494 to AY599497 and AY582798. The MODELTEST program, version 3.06 (Posada and Crandall, 1998) was used to identify the evolutionary model that best fitted the data, the divergence matrix being generated using the beta version of the PAUP 4.0 program (Swofford, 2002) based on the 
Table 2 - Internal primers for the mitochondrial DNA ND1 flanking regions of Cebus apella and several Saguinus species.

\begin{tabular}{|c|c|c|c|}
\hline $\begin{array}{l}\text { Primers } \\
\left(5^{\prime} \text { to } 3^{\prime}\right)\end{array}$ & $\begin{array}{c}5 \\
\text { positions }\end{array}$ & Primer sequences & $\begin{array}{l}\text { Saguinus } \\
\text { specimens }\end{array}$ \\
\hline A & - & $\begin{array}{l}\text { 5' CTA CGT GAT CTG } \\
\text { AGT TCA GAC CGG } 3\end{array}$ & $\begin{array}{l}\text { all species } \\
\text { sequenced }\end{array}$ \\
\hline A2SF & 62 & $\begin{array}{l}5, \text { CAC TCA CAG AAC } \\
\text { GAA AAA TCC TAG GC 3' }\end{array}$ & S. fuscicollis \\
\hline $\mathrm{A} 2 \mathrm{SO}$ & 64 & $\begin{array}{l}\text { 5' CTC ACA GAA CGA } \\
\text { AAA GTG CTA GGC 3' }\end{array}$ & S. oedipus \\
\hline A2SL & 61 & $\begin{array}{l}\text { 5' ACA CTC ACA GAA } \\
\text { CGA AAA GTA TTG GG } 3 \text {, }\end{array}$ & S. leucopus \\
\hline $\mathrm{A} 2 \mathrm{SM}$ & 61 & $\begin{array}{l}\text { 5' ACA CTC ACA GAA } \\
\text { CGA AAG ATC CTA G } 3\end{array}$ & S. mystax \\
\hline $\mathrm{A} 2 \mathrm{SB}$ & 61 & $\begin{array}{l}\text { 5' ACA CTC ACA GAG } \\
\text { CGA AAA GTA TTA GG 3, }\end{array}$ & $\begin{array}{l}\text { S. bicolor, } \\
\text { S. midas }\end{array}$ \\
\hline A2APE & 124 & $\begin{array}{l}\text { 5' CCA TAT GGA GTA } \\
\text { CTC CAA CCA ATC } 3 \text { ' }\end{array}$ & Cebus apella \\
\hline A3SN & 395 & $\begin{array}{l}\text { 5' CAC TAC GAG CTG } \\
\text { TAG CCC AAA CAA T } 3\end{array}$ & $\begin{array}{l}\text { S. midas, } \\
\text { S. oedipus }\end{array}$ \\
\hline A3SF & 395 & $\begin{array}{l}\text { 5' CAC TAC GAG CTG } \\
\text { TAG CTC AAA CAA T } 3 \text {, }\end{array}$ & $\begin{array}{l}\text { S. fuscicollis, } \\
\text { S. leucopus }\end{array}$ \\
\hline A3SB & 414 & $\begin{array}{l}\text { 5' GAC AAT CTC GTA } \\
\text { CGA AGT TAC CCT } 3\end{array}$ & S. bicolor \\
\hline A3SM & 396 & $\begin{array}{l}\text { 5' GCT ACG AGC TGT } \\
\text { AGC TCA AAC AAT 3', }\end{array}$ & S. mystax \\
\hline A3APE & 411 & $\begin{array}{l}\text { 5' CCA GAC CAT TTC } \\
\text { ATA CGA AGT CAC } 3\end{array}$ & Cebus apella \\
\hline $\mathrm{C}\left(3^{\prime}\right.$ to $\left.5^{\prime}\right)$ & - & $\begin{array}{l}\text { 5' CCC GAT AGC TTA } \\
\text { TTT AGC TGA CCT TAC } \\
\text { T 3, }\end{array}$ & $\begin{array}{l}\text { all species } \\
\text { sequenced }\end{array}$ \\
\hline
\end{tabular}

model parameters selected by the MODELTEST program. Maximum-parsimony (MP), neighbor joining (NJ) and maximum-likelihood (ML) analyses were performed with the PAUP 4.0 program using an heuristic search. The robustness of the phylogenetic hypothesis obtained was tested by bootstrapping (Felsenstein, 1985) with 2000 pseudo-replicates for NJ and MP, and 500 for ML. The criterion adopted to evaluate robustness was to consider bootstrap values equal or superior to $90 \%$ as being statistically significant. The Bremer Decay indexes were obtained using the SEPAL program (Salisbury, 1999, 2000).

\section{Results and Discussion}

For the 21 Saguinus specimens investigated no insertions or deletions (indels) were detected in the alignments and the average percentage nucleotide composition was thymine (T) 26.5, cytosine (C) 30.1, adenine (A) 31.5 and guanine $(\mathrm{G})$ 11.9. The ND1 nucleotide frequencies obtained for Saguinus were similar to the values previously obtained for other genera of Callitrichinae and Cebus (Tagliaro, 1997). The average transition/transversion rate was 3.6 (without the outgroup) and the saturation test using the ND1 Saguinus sequences detected no saturation at the intrageneric level at any of the codon positions.

The maximum-likelihood best-fit model selected by the MODELTEST program for the 22 samples was the Hasegawa-Kishino-Yano (HYK) model (Hasegawa et al., 1985), which takes into account the proportion of invariable sites $(\mathrm{I})$, gamma $(\mathrm{G})$ and the gamma distribution shape parameter $(\mathrm{HKY}+\mathrm{I}+\mathrm{G})$. The settings from the best-fit model selected by hierarchical likelihood ratio tests (HLRTs) were: base frequencies ( $\mathrm{A}=0.3479, \mathrm{C}=0.3105$, $\mathrm{G}=0.0982, \mathrm{~T}=0.2434)$; the proportion of invariable sites (Pinv $=0.5802)$; gamma distribution shape parameter (Rates $=$ gamma, Shape $=3.5920)$; transition/transversion rate $($ Tratio $=7.1012)$; and number of substitution types $(\mathrm{Nst}=2)$.

\section{The small-bodied and large-bodied size division}

The trees obtained in this study using different methods (MP, NJ and ML) showed the same general topology (Figure 2), with the genus Saguinus divided into two major clades, one containing the two S. fuscicollis subspecies and the other, the larger species (S. oedipus, S. leucopus, $S$. mystax, S. midas and $S$. bicolor). The small and large-bodied size division was initially proposed by Jacobs-Cropp et al. (1999) and it was also supported by the

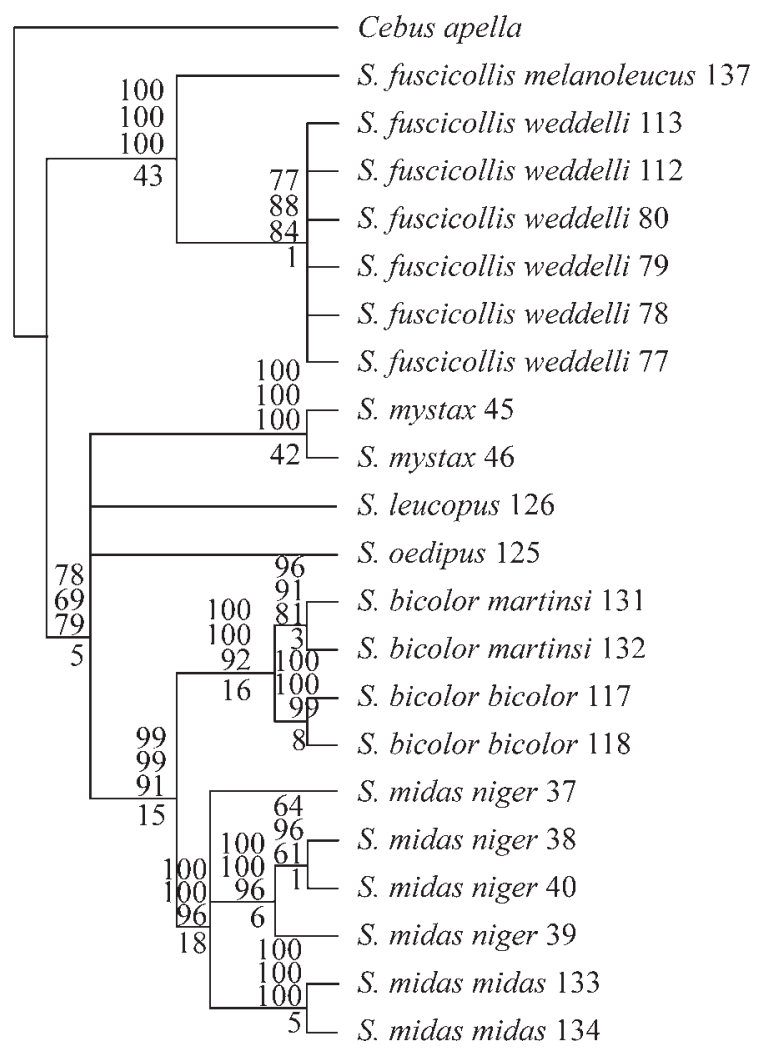

Figure 2 - Consensus maximum-parsimony (MP), neighbor joining (NJ) and maximum likelihood (ML) tree for the genus Saguinus. The bootstrap values are given above the branches: top $=$ MP, 2000 replicates; middle $=$ NJ, 2000 replicates; bottom $=$ ML, 500 replicates. The Bremer Decay indices are given below the branches. 
results of Canavez et al. (1999). Other studies based on morphological features (Hershkovitz, 1977; Natori and Hanihara, 1992) did not agree with this division based on body size, but molecular data indicate that it may be an important morphological character that should be used to clarify the evolutionary history of this genus.

\section{The bare-face and hairy-face tamarin sections}

The monophyletic origin of the bare-faced $S$. leucopus and $S$. oedipus was not evident in the present analysis since the bootstrap values were not significant in any of the three distinct topologies obtained by MP, NJ and ML. Although our data did not show significance joining $S$. leucopus and $S$. oedipus, other molecular and morphological studies (Jacobs et al., 1995; Jacobs-Cropp et al., 1999; Natori, 1988; Natori and Hanihara, 1992) and the geographical distribution (Figure 1) of these species indicate that they probably are sister taxa and could be grouped together (oedipus group) as proposed by Hershkovitz (1977).

Our phylogenetic analysis strongly supports a clade joining the bare-faced Saguinus bicolor and the hairy-faced S. midas (bootstrap values: $\mathrm{MP}=99 \%, \mathrm{NJ}=99 \%, \mathrm{ML}=$ $91 \%$; Decay index $=15$ ), these species are geographically closely related (see Figure 1). The close relationship which we found between $S$. midas and S. bicolor was first noted by Natori and Hanihara (1992) and supported by Rylands et al. (1993), with these authors even proposing that $S$. midas and S. bicolor should together form an independent group. Our results show $S$. midas-S. bicolor grouping with the barefaced tamarins of northwestern South America (Saguinus oedipus oedipus, $S$. oedipus geoffroyi, $S$. leucopus). Hershkovitz (1977), considering morphological features and geographical distribution, suggested that the hairy-faced trait is the most primitive and grouped all the bare-faced tamarins together, although he recognized that $S$. bicolor acquired the bare-faced condition independently of the bare-faced tamarins of northwestern South America. According to Hershkovitz (1977), the S. bicolor group may have gained the bare-faced condition from a founder colony of hairyfaced tamarins separated by a river-bend cutoff from the ancestral stock on the south bank of the Amazon west of the Rio Madeira. The Saguinus oedipus group arose independently from an upper Amazonian stock of hairy-faced tamarins, spread northward along the eastern base of the Andes, then west into northern Colombia and Middle America. Although our results do not support the division of Saguinus species based on the presence or absence of facial-hair, we agree with Hershkovitz that the bare-faced condition may have arisen in two different lineages by convergence.

Are S. bicolor and S. midas midas more closely related to each other than to $S$. midas midas and $S$. midas niger?

At the species level, all our ND1 phylogenetic trees (Figure 2) showed that all the representatives grouped ac- cording to the morphological classification of Hershkovitz (1977). The suggestion that S. bicolor and S. midas could be subspecies of the same species (Canavez et al., 1999), was not supported by our results but they were consistent with those of Meireles et al. (1997) and Jacobs-Cropp et al. (1999), joining S. bicolor and S. midas as sister groups. One possible reason for this discrepancy could be the fact that both we and Jacobs-Cropp et al. (1999) used mitochondrial sequences which evolve faster than the nuclear sequences as used by Canavez et al. (1999).

\section{The subspecies of Saguinus midas}

Surprisingly, the $S$. midas niger clade was not strongly supported by MP (bootstrap $=64 \%$ ) or NJ (bootstrap $=77 \%$ ) analysis, although ML analysis (bootstrap = $96 \%$ ) indicated that the four S. midas niger specimens were not joined together at all, with $S$. m. niger specimen 37 being isolated in its own branch. Distance values showed that specimen 37 diverged by 0.015 from the other $S$. m. niger specimens, this value being closely associated with the divergence found between subspecies of the same species, i.e. S. bicolor bicolor $\mathrm{x}$ S. bicolor martinsi (0.017 to 0.018), $S$. midas midas $\mathrm{x} S$. midas niger (0.017 to 0.021$)$ (Table 3$)$. Since the distances observed between $S$. m. niger specimen 37, S. midas midas 133-134 and S. midas niger specimens 38-39-40 were almost the same, we concluded that probably there is a third subspecies with a similar morphotype to $S$. midas niger. Unfortunately, there were no details on which margin of the Tocantins river the $S$. midas niger specimens were captured.

\section{Are S. fuscicollis melanoleucus and S. fuscicollis weddelli different species?}

Although we sampled only one S. fuscicollis melanoleucus specimen we decided to use our ND1 mitochondrial DNA data to test Coimbra-Filho's proposal that this morphotype should be reclassified as a different species (Coimbra-Filho, 1990). In all the phylogenetic trees Saguinus fuscicollis melanoleucus was basal to $S$. fuscicollis weddelli but this arrangement was not statistically significant for any of the methods used to construct the trees. In fact, the distance matrix (Table 3) showed that the genetic distance values between this $S$. f. melanoleucus morphotype and $S$. fuscicollis weddelli range from 0.002 to 0.005 , which are similar to the genetic distances obtained between the $S$. fuscicollis weddelli specimens (0 to 0.003). Contrasting with our results, Jacobs-Cropp et al., (1999) used cytochrome $b$ and the D-loop mitochondrial DNA data to obtain genetic distance values agreeing with the traditional classification of Hershkovitz (1977), in which both S. f. melanoleucus and S. f. weddelli are considered as subspecies of $S$. fuscicollis. There are two possible explanations for these discrepancies, one being that in our study the S. f. melanoleucus specimen (specimen 137) was not correctly identified (improbable because the blood sample was 


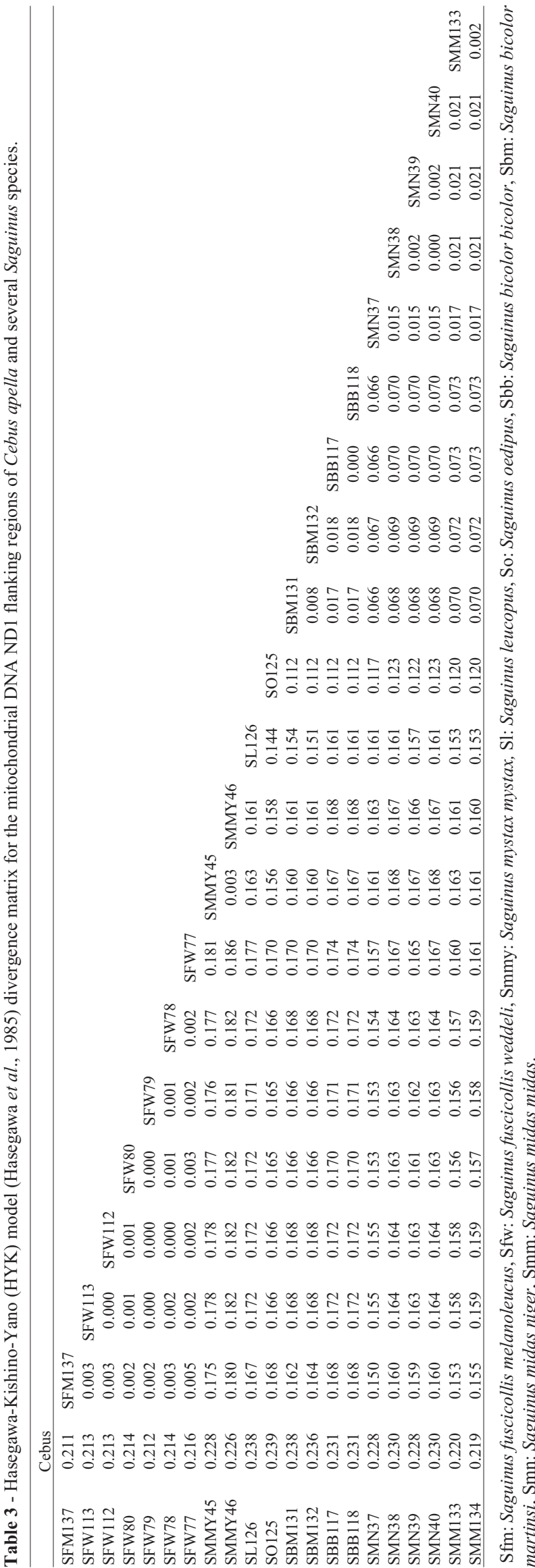

taken from this animal in its natural forest environment) and the other being that S. f. melanoleucus and S.f. weddelli are in fact the same taxon with regional morphological differences. Unfortunately, there is no other molecular study published using more than one individual of the same $S$. fuscicollis subspecies, which means that the range of divergence values of each of these subspecies cannot be verified.

\section{Conservation status of Saguinus}

Primates are important indicators for tropical forests and are a fundamental component for the establishment of biodiversity conservation strategies in biomes, regions and countries (Rylands et al., 1997; Sechrest et al., 2002). According to the Mace-Lande system, recently adopted by the International Union for Conservation of Nature and Natural Resources (IUCN), 35 percent of Neotropical primate taxa are threatened (Rylands et al., 1997). Brazil is not only the country with the highest diversity of primates (76 species and a total of 128 species and subspecies) but also has the highest number of threatened species and subspecies of primates, with 38 species and a total of 69 species and subspecies being considered as threatened (Rylands et al. 1997). Due to an almost complete lack of information on the populations of most of the callitrichids, decisions on their conservation status are based almost entirely on the size of their geographic range and a gross overview of the state of destruction and development of the regions involved. Such decisions are also based on taxonomic classifications that depend on morphological studies including pelage color (Rylands et al., 1993). Two genera of Callitrichinae (Leontopithecus and Callimico) and 16 of the total of 55 species and subspecies are considered threatened, including five Saguinus species and subspecies, with S. bicolor bicolor and $S$. oedipus being considered endangered and $S$. nigricollis hernandezi, S. imperator imperator and $S$. leucopus vulnerable (Rylands et al., 1997).

The study presented in this paper reinforces the value of molecular techniques in confirming traditional taxonomic classifications, our results pointing to the existence of a subspecies which has similar morphology to $S$. midas niger but which can be differentiated from $S$. midas niger on the basis of molecular data. None of the $S$. midas subspecies are at present considered threatened, mainly because of their wide geographical distribution (Figure 1), but since our molecular data indicates the possible existence of a new S. midas subspecies we should be alert to the conservation needs of this new subspecies because we have no idea as to its distribution or population size. Furthermore, the distribution area of $S$. midas niger is suffering pressure from deforestation for agriculture and cattle raising, which may mean that new taxa can disappear before even being described. There have been few molecular studies of New World monkeys using several individuals of the same species or subspecies but detailed studies at this level may re- 
veal that the richness of the Amazonian primates is being underestimated.

\section{Acknowledgments}

This study was supported by grants to M.J.S. from the Nuffield Foundation, the Royal Society, and the Northern Ireland Development and Research Council. The Brazilian agency CNPq supported C.H.T. We thank Dr. José Augusto Pereira Carneiro Muniz (Centro Nacional de Primatas, Belém, Pará, Brazil), Dr. Aldemar Coimbra-Filho and Dr. Alcides Pissinati (both from the Centro de Primatologia do Rio de Janeiro, Brazil) and Arlindo Pinto de Souza Jr. (Universidade Federal do Pará, Brazil) for providing the Saguinus blood samples used in our research. We are grateful to Dr. Colin Robert Beasley for help with correcting the English.

\section{References}

Avise JC (1994) Molecular Markers, Natural History and Evolution. Chapman and Hall, New York, 511 pp.

Barroso CML, Schneider H, Schneider MPC, Sampaio I, Harada ML, Czelusniak J and Goodman M (1997) Update on the phylogenetic systematics of the New World monkeys: Further DNA evidence for placing the pygmy marmoset (Cebuella) within the genus Callithrix. International Journal of Primatology 18:651-674.

Canavez FC, Moreira MAM, Simon F, Parham P and Seuánez HN (1999) Phylogenetic relationships of the Callitrichinae (Platyrrhini, Primates) based on $\beta_{2}$-microglobulin DNA sequences. American Journal of Primatology 48:225-236.

Chaves R, Sampaio I, Schneider MP, Schneider H, Page SL and Goodman M (1999) The place of Callimico goeldii in the Callitrichine phylogenetic tree: Evidence from von Willebrand factor gene intron II sequences. Molecular Phylogenetics and Evolution 13:392-404.

Coimbra-Filho AF (1990) Sistemática, distribuição geográfica e situação atual dos símios brasileiros (Platyrrhini, Primates). Revista Brasileira de Biologia 50:1063-1079.

Felsenstein J (1985) Confidence limits on phylogenies: An approach using the bootstrap. Evolution 39:783-791.

Goodman M, Porter CA, Czelusniak J, Page SL, Schneider H, Shoshani J, Gunnell G and Groves CP (1998) Toward a phylogenetic classification of primates based on DNA evidence complemented by fossil evidence. Molecular Phylogenetics and Evolution 9:585-598.

Hall TA (1999) BioEdit: A user-friendly biological sequence alignment editor and analysis program for Windows 95/98/NT. Nucleic Acids Symposium Series 41:95-98.

Hasegawa M, Kishino H and Yano T (1985) Dating the human-ape splitting by a molecular clock of mitochondrial DNA. Journal of Molecular Evolution 22:160-174.

Hershkovitz P (1977) Living New World Monkeys (Platyrrhini). With an Introduction to Primates. v. 1. The University of Chicago Press, Chicago and London, 1117 pp.

Hershkovitz P (1979) Races of the emperor tamarin, Saguinus imperator Goeldi (Callitrichidae, Primates). Primates 20:277287.
Hershkovitz P (1982) Subspecies and geographic distribution of black-mantle tamarins, Saguinus nigricollis Spix (Primates: Callitrichidae). Proceedings of the Biological Society of Washington 95:647-656.

Jacobs SC, Larson A and Cheverud JM (1995) Phylogenetic relationships and orthogenetic evolution of coat color among tamarins (genus Saguinus). Syst Biol 44:515-532.

Jacobs-Cropp S, Larson A and Cheverud JM (1999) Historical biogeography of Tamarins, genus Saguinus: The molecular phylogenetic evidence. American Journal of Physical Anthropology 108:65-89.

Kumar S, Tamura K, Jakobsen IB and Nei M (2001) Mega 2: Molecular evolutionary genetics analysis software. Bioinformatics 17:1244-1245.

Meireles C, Sampaio I, Schneider H, Ferrari SF, Coimbra-Filho AF, Pissinati A and Schneider MPC (1997) A comparative study of eleven protein systems in tamarins, genus Saguinus (Platyrrhini, Callitrichinae). Brazilian Journal of Genetics 20:13-19.

Mittermeier RA, Rylands AB and Coimbra-Filho AF (1988) Systematics: Species and subspecies - An update. In: Mittermeier RA, Rylands AB, Coimbra-Filho AF and da Fonseca GAB (eds) Ecology and Behaviour of Neotropical Primates. v. 2. World Wildlife Fund, Washington, D.C., pp 13-75.

Natori M (1988) A cladistic analysis of interspecific relationships of Saguinus. Primates 29:263-276.

Natori M and Hanihara T (1992) Variations in dental measurements between Saguinus species and their systematic relationships. Folia Primatol 58:84-92.

Pastorini J, Forstner MRJ, Martin RD and Melnick DJ (1998) A reexamination of the phylogenetic position of Callimico (Primates) incorporating new mitochondrial DNA sequence data. Journal of Molecular Evolution 47:32-41.

Posada D and Crandall KA (1998) MODELTEST: Testing the model of DNA substitution. Bioinformatics 14:817-818.

Rosenberger AL (1978) Loss of incisor enamel marmosets. Journal of Mammalogy 59:207-208.

Rosenberger AL (1981) Systematics: The higher taxa. In: Coimbra-Filho AF and Mittermeier RA (eds) Ecology and Behavior of Neotropical Primates. Academia Brasileira de Ciências, Rio de Janeiro, pp 9-27.

Rylands AB, Coimbra-Filho AF and Mittermeier RA (1993) Systematics, geographic distribution, and some notes on the conservation status of the Callitrichidae. In: Rylands AB (ed) Marmosets and Tamarins Systematics, Behaviour, and Ecology. Oxford University Press, Oxford, New York, Tokyo, pp 11-77.

Rylands AB, Mittermeier RA and Rodriguez-Luna, E (1995) A species list for the New World Primates (Platyrrhini): Distribution by country, endemism, and conservation status according to the Mace-Land system. Neotropical Primates 3:113-160.

Rylands AB, Mittermeier RA and Rodríguez-Luna E (1997) Conservation of Neotropical Primates: Threatened species and an analysis of Primate diversity by country and region. Folia Primatol 68:134-160.

Rylands AB, Schneider H, Langguth A, Mittermeier RA, Groves CP and Rodríguez-Luna E (2000) An assessment of the diversity of the New World Primates. Neotropical Primates 8:61-93. 
Salisbury BA (1999) Strongest evidence: Maximum apparent phylogenetic signal as a new cladistic optimality criterion. Cladistics 15:137-149.

Salisbury BA (2000) Strongest evidence revised. Cladistics 16(394-402.

Sambrook J, Fritsch E and Maniatis T (1989) Molecular Cloning: A Laboratory Manual. Cold Spring Harbor Laboratory Press, New York.

Schneider H, Schneider MPC, Sampaio I, Harada ML, Stanhope M, Czelusniak J and Goodman M (1993) Molecular phylogeny of the New World monkeys (Platyrrhini, Primates). Molecular Phylogenetics and Evolution 22:225-242.

Schneider H, Sampaio I, Harada ML, Barroso CML, Schneider MPC, Czelusniak J and Goodman M (1996) Molecular phylogeny of the New World monkeys (Platyrrhini, Primates) based on two unlinked nuclear genes: IRBP intron 1 and gama-globin sequences. American Journal of Physical Anthropology 100:153-179.

Schneider H (2000) The current status of the New World monkey phylogeny. Anais da Academia Brasileira de Ciências 72:165-172.

Sechrest W, Brooks TM, Fonseca GAB, Konstant WR, Mittermeier RA, Purvis A, Rylands AB and Gittleman JL (2002) Hotspots and the conservation of evolutionary history. Proceedings of the National Academy of Sciences 99:2067-2071.
Swofford DL (2002) PAUP* Phylogenetic Analysis Using Parsimony (*and other Methods) Version 4. Sinauer Associates, Sunderland, Massachusetts.

Tagliaro CH (1997) A filogenia molecular na subfamilia Callitrichinae (Platyrrhini, Primates): As relações intergenéricas e intragenéricas de Callithrix. PhD Thesis, Universidade Federal do Pará, Belém, Brazil, 187 pp.

Tagliaro CH, Schneider MPC, Schneider H, Sampaio IC and Stanhope M (1997) Marmoset phylogenetics, conservation perspectives, and evolution of the mtDNA control region. Molecular Biology and Evolution 14:674-684.

Tagliaro CH, Schneider MPC, Schneider H, Sampaio I and Stanhope M (2000) Molecular studies of Callithrix pygmaea (Primates, Platyrrhini) based on transferrin intronic and ND1 regions: Implications for taxonomy and conservation. Genetics and Molecular Biology 23:729-737.

Thompson JD, Higgins DG and Gibson TJ (1994) CLUSTAL W: Improving the sensitivity of progressive multiple sequence alignment through sequence weighting, positions-specific gap penalties and weight matrix choice. Nucleic Acids Research 22:4673-4680.

Van Roosmalen MGM, Van Roosmalen T, Mittermeier RA and Rylands AB (2000) Two new species of marmoset, genus Callithrix Erxleben, 1777 (Callitrichidae, Primates) from Tapajós/Madeira interfluvium, South Central Amazonia, Brazil. Neotropical Primates 8:2-18.

Xia X and Xie Z (2001) DAMBE: Data analysis in molecular biology and evolution. Journal of Heredity 92:371-373.

Associate Editor: Sérgio Furtado dos Reis 